\title{
The Syntax, Semantics, and Prosody of German "VP"-fronting
}

\author{
Vera Lee-Schoenfeld \& Anya Lunden \\ University of Georgia
}

German allows fronting of VPs containing a derived subject, i.e. underlying direct object, as illustrated by the fronted unaccusative VP in (1) and the fronted passive VP in (2) (see also Hankamer \& Lee-Schoenfeld 2005). Since German is a verb-second (V2) language, the fronted constituent occupies the initial position (the German 'Vorfeld' or Spec CP, see e.g. Frey 2006), and the finite verb sits in $\mathrm{C}$.

(1) [Ein Fehler unterlaufen] ist ihrem Mann. a.NOM mistake occurred has her.DAT husband

'What happened was that her husband made a mistake.'

(2) [Viele Jobs angeboten] wurden einem damals. many.NOM jobs offered were.PASS one.DAT then

'We were offered many jobs back then.'

Unlike examples with fronted unaccusative or passive VPs, sentences like (3), found in Haider 1990, crucially depend on a certain post-fronting context and a rise-fall, bridge-contour intonation (Büring 1997) in order to be acceptable. The rise marks the so-called I(ntonation)Topic, also known as contrastive topic, and the lowest point of the fall marks the Focus (Jacobs 1997, Molnár \& Rosengren 1997, Steube 2001, Féry 2007, et al.). The syllables bearing the rise and the fall are given in caps. "/ marks the beginning of the constituent bearing the rise, and "I" marks the end of the fall.

(3) $[/$ Ein AUßenseiter gewonnen $]$ hat $\{$ hier noch NIE ||$*$ im $\quad$ zweiten Rennen $\}$. a.NOM outsider won has here yet never / in-the second race

'It has never happened here that an outsider won.'

The verb here is unergative and therefore has an agentive subject, introduced in Spec $v \mathrm{P}$. That is, unlike in (1) and (2), this subject is not part of the lexical VP. What is fronted in (3) is then a more structurally complex verbal constituent. Even transitive verbs have been argued to be frontable together with their subject and object(s). Example (4) is from Wurmbrand 2004. Notice that neither (3) nor (4) is acceptable given the second post-fronting context, a fact to be elaborated on below.

(4) [/Ein Millionär einem Studenten einen WAgen geschenkt $]$ hat $\left\{\right.$ hier noch NIE $\left.\backslash \quad\right|^{*}$ gestern $\}$. a.nom millionaire a.dat student a.acc car given has here yet never | yesterday 'It has never happened here that a millionaire gave a student a car.'

The pitch track pair in (5) illustrates the intonation difference between fronted bare VP and fronted agentive $v \mathrm{P}$. The bridge contour occurs with the agentive $v \mathrm{P}$ in the (b)-example, not the VP in the (a)-example. Fronted VPs can also be I-Topics (as can DPs, PPs, APs, AdvPs, etc.), but, crucially, they do not have to be. Given the post-fronting context in the (a)-example, the fronted VP is not a contrastive topic but rather contrastively focused (as in "a TIger has escaped, not an ELephant gone wild"). The right edge of the fronted portion of each sentence is marked with a right bracket under the pitch track. 
(5) a. [Ein Tiger entwichen] ist dem Wanderzirkus neulich. a.NOM tiger escaped has the.DAT travel-circus the-other-day 'A tiger got away from the travel circus the other day.'

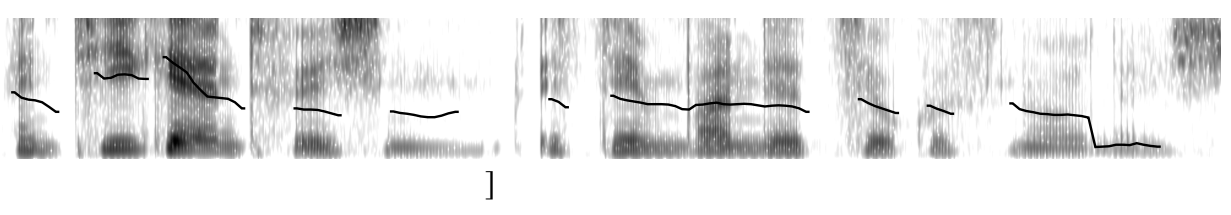

b. [Ein Außenseiter gewonnen] hat hier noch nie. an.NOM outsider won has here yet never 'It has never happened here that an outsider won.'
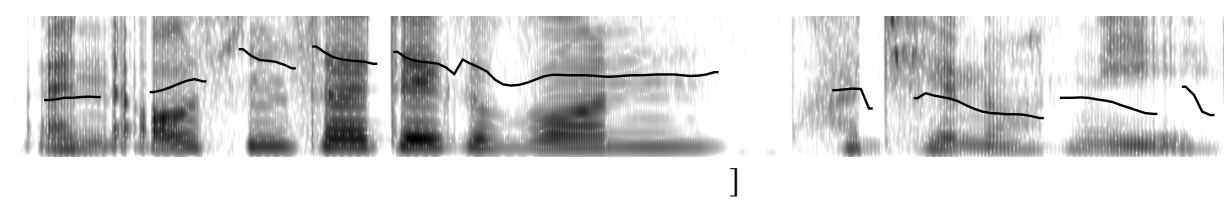

The main question addressed here concerns the post-fronting context and bridge-contour intonation needed to make examples like (3) and (4) acceptable. Supported by the results of two experimental studies on the acceptability of fronted transitive $v$ Ps (see Lee-Schoenfeld 2010 and Lee-Schoenfeld \& Lunden in prep), the claim is that speakers tend to allow the fronted constituent as long as it can be fronted as a single information-structural unit (see Webelhuth 1990 and de Kuthy \& Meurers 2003) and therefore be given a thetic (non-categorical, i.e. noncompositional) interpretation (see Kuroda 1972 and Ladusaw 1994). If the fronted verbal constituent is the lexical VP, there is no 'subject' triggering an interpretation act that is separate from the interpretation of the predicate. If, on the other hand, the fronted verbal constituent is an agentive $\nu \mathrm{P}$, the presence of a 'subject' normally triggers a categorical interpretation. Only if the content of $\nu \mathrm{P}$ is quantified over rather than asserted can a thetic interpretation be triggered. ${ }^{1}$ In order for this to work, the participants in the situation described by the fronted verb must be nonspecific, i.e. not refer to particular entities. Hence the well-known definiteness effect that holds for the subject in fronted verbal constituents (Haider 1990, 2006, Wurmbrand 2004). Given the post-fronting contexts marked as ungrammatical in (3) and (4), the DPs denoting the participants in the situation, whether headed by a definite or indefinite $\mathrm{D}$, will be interpreted as specific and therefore cause the construction to be unacceptable.

The pitch track example in (6) shows the prosodic details of I-Topicalization and how the bridgecontour intonation turns the fronted $v \mathrm{P}$ into one large prosodic phrase, namely its own Intonational Phrase (IP) (see Féry 2007), ending with a high edge tone. This leads to an IP within an IP, the latter spanning the entire sentence.

(6) [/Ein ProFESsor eine VORlesung gehalten] hat hier noch NIE $\$. a.NOM professor a.ACC lecture held has here yet never 'It has never happened here that a professor gave a lecture.'

\footnotetext{
${ }^{1}$ Thank you to Michael Covington for pointing this out.
} 


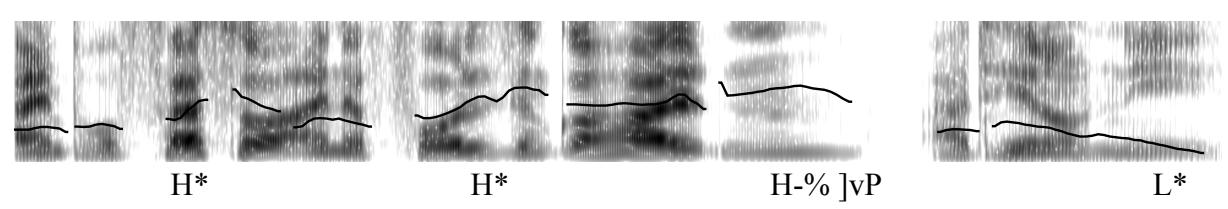

The high plateau of the bridge-contour stretches from the rightmost fronted DP, bearing a high pitch accent $\left(\mathrm{H}^{*}\right)$ through the verb, which we take to be associated with a phrasal accent high (H-), up to the right edge of the fronted constituent (H\%) (see Pierrehumbert 1980 and Beckman \& Pierrehumbert 1986 for ToBI and Grice et al. 2005 for the G(erman)ToBI). Then there is a gradual fall to the low-pitched focus. Since a transitive $v \mathrm{P}$ contains at least two DPs, which each constitute a Major Phrase (MaP), there is a noticeable fall after the first DP before the high plateau starts with the high pitch peak of the second DP. Importantly, the high boundary tone causes the fronted constituent has a whole to have rising pitch and thereby condenses it into a single I-Topic.

Information-structurally, an I-Topic is an instance of a contrastive topic, which is distinct from a contrastive focus in that it does not merely put emphasis on the fronted material in contrast to something else that might have been mistakenly uttered before (as in "THIS, I said, not THAT"). Contrastive topics, which can be frame-setting, implicational, or partial (Büring 1997), have as their primary characteristic that they are chosen out of a set of inferable alternatives, so that the sentence could have been about something else from a given list of similar choices. They are basically a combination of topic and focus, brought up by the speaker in the context of other currently relevant topic-focus combinations. The context for the I-Topicalization in (6) could be, for example, a conversation taking place at a popular coffee shop/bar in town, where the interlocutors are discussing what kinds of performances are coming up. Upon hearing one of the interlocutors, who is a professor at the local university, expressing her strong interest in signing up for one of the open mic slots, another interlocutor could utter (6), implying that a professor's performance may not be appropriate for the venue, while that of an actual musician would be welcomed.

In sum, I-Topicalization, with its distinct bridge-contour intonation, makes fronting possible for a constituent that is normally too complex to undergo this syntactic operation. Thus, just as ITopicalization is known to enable movement of elements that normally do not scramble (like non-specific indefinite DPs and separable prefixes), and just as it is known to allow the moving constituent to cross clause-boundaries (see Steube 2001), it also licenses the otherwise ungrammatical fronting of agentive $v$ Ps. We are dealing with an information-structurally driven syntactic operation, then, which is made possible prosodically. This leads us to at least two interface questions: (i) how do information-structure markings (like [ ] TOPIC and [ ] Focus) become a part of the syntax and (ii) how does the phonology know that, unlike other constituents marked for special information structure, agentive $v$ Ps have to be contrastive topics, i.e. get the bridge-contour intonation? We leave this to be worked out in the full-length version of this paper.

\section{References}

Beckman, Mary \& Janet Pierrehumbert. 1986. Intonational structure in English and Japanese. Phonology Yearbook 3: 255-310. 
Büring, Daniel. 1997. The meaning of topic and focus: The $59^{\text {th }}$ Street bridge accent. London: Routledge.

Féry, Caroline. 2007. The prosody of topicalization. In K. Schwabe and S. Winkler (eds.) On Information Structure, Meaning and Form: Generalizations Across Languages, 69-86. Amsterdam: John Benjamins.

Frey, Werner. 2006. Contrast and movement to the German prefield. In V. Molnár \& S. Winkler (eds.) The Architecture of Focus, 235-264. Berlin: Mouton de Gruyter.

Grice, Martine, Stefan Baumann, \& Ralf Benzmüller. 2005. German intonation in autosegmental-metrical phonology. In Sun-Ah Jun (ed.) Prosodic Typology: The Phonology and Intonation and Phrasing, 55-83. Oxford University Press.

Haider, Hubert. 1990. Topicalization and other puzzles of German syntax. In G. Grewendorf \& W. Sternefeld (eds.) Scrambling and barriers: 93-112. Amsterdam: Benjamins.

Haider, Hubert. 2006. Mittelfeld phenomena. In M. Everaert \& H. van Riemsdijk (eds.) The Syntax Companion (SynCom) Vol. 3. Malden, MA: Blackwell.

Hankamer, Jorge \& Vera Lee-Schoenfeld. 2005. What moves in German VP-‘topicalization'? LSA annual meeting, Oakland, CA, January 2005.

Jacobs, Joachim. 1997. I-Topikalisierung. Linguistische Berichte 168: 91-133.

Kuroda, Sige-Yuki. 1972. The categorical and the thetic judgments. Foundations of Language 9, 153-185.

Kuthy, Kordula de \& W. Detmar Meurers. 2003. The secret life of focus exponents, and what it tells us about fronted verbal projections. In S. Müller (ed.) Proceedings of the HPSG03 Conference. CSLI Publications.

Ladusaw, William. 1994. Thetic and categorical, stage and individual, weak and strong. In M. Harvey \& L. Santelmann (eds.) Proceedings from Semantics and Linguistic Theory IV. Ithaca, NY: Cornell University.

Lee-Schoenfeld, Vera. 2010. VP-fronting: A matter of syntax? Deutsche Gesellschaft für Sprachwissenschaft (DGfS) annual meeting, Berlin, Germany, February 25, 2010.

Lee-Schoenfeld, Vera \& Anya Lunden. In prep. The syntax, information structure, and prosody of German 'VP'-fronting. Ms. University of Georgia.

Molnár, Valeria \& Inger Rosengren. 1997. Zu Jacobs' Explikation der I-Topikalisierung. Linguistische Berichte 169: 211-247.

Pierrehumbert, Janet. The phonetics and phonology of English intonation. PhD dissertation, MIT.

Steube, Anita. 2001. Grammatik und Pragmatik von Hutkonturen. Linguistische Arbeitsberichte 77: 7-29.

Webelhuth, Gert. 1990. Diagnostics for structure. In G. Grewendorf \& W. Sternefeld (eds.) Scrambling and Barriers, 40-75. Amsterdam: John Benjamins.

Wurmbrand, Susi. 2004. No TP fronting meets Nearly Headless Nick. Ms., University of Connecticut, Storrs. 